Intersections

Canadian Journal of Music

Revue canadienne de musique
Intersections CANADAN TOURAA OP NUSIC

\title{
John Deathridge. 2008. Wagner: Beyond Good and Evil. Berkeley: University of California Press. xiii, 302 pp. ISBN 978-0-520-25453-4.
}

\section{Daniel Sheridan}

Volume 30, numéro 1, 2010

URI : https://id.erudit.org/iderudit/1003506ar

DOI : https://doi.org/10.7202/1003506ar

Aller au sommaire du numéro

Éditeur(s)

Canadian University Music Society / Société de musique des universités canadiennes

ISSN

1911-0146 (imprimé)

1918-512X (numérique)

Découvrir la revue

Citer ce compte rendu

Sheridan, D. (2010). Compte rendu de [John Deathridge. 2008. Wagner: Beyond Good and Evil. Berkeley: University of California Press. xiii, 302 pp. ISBN 978-0-520-25453-4]. Intersections, 30(1), 137-142.

https://doi.org/10.7202/1003506ar

All Rights Reserved (C Canadian University Music Society / Société de musique des universités canadiennes, 2011
Ce document est protégé par la loi sur le droit d'auteur. L'utilisation des services d'Érudit (y compris la reproduction) est assujettie à sa politique d'utilisation que vous pouvez consulter en ligne.

https://apropos.erudit.org/fr/usagers/politique-dutilisation/ 
Chapter 7, "Postlude," is a brief selection of reminiscences from a trip Mooser made to Munich after the First World War.

The book closes with two appendixes: a genealogy of the Romanovs and a selection of reviews and articles that Mooser wrote for the Journal de St Pétersbourg. By beginning with two reviews by Mooser's predecessor, Woodside provides a context in which to appreciate the shift Mooser brought with his outspoken support of the New Russian School of composers and his dislike of Anton Rubenstein and Tchaikovsky. The reviews illustrate both Mooser's critical style and the consistency of his views across private and professional writings. Woodside's selections provide a good balance of Mooser's reflections on broad topics (e.g., the right of a composer or performer to make alterations to an earlier composer's work) as well as reviews of specific performances.

This edition of Mooser's memoirs is a valuable source for musicologists and cultural historians interested in the musical climate of St. Petersburg at the turn of the century. From the centre of St. Petersburg's musical world Mooser provided important first-hand accounts of the people and events of his time. However, as his writings make abundantly clear, he was not an impartial observer but rather a very opinionated participant. In the first chapter he accuses Rubenstein's works of "oozing facile pathos and treacly sentimentality" and writes joyfully of how a series of concerts offered him the opportunity, "always eagerly seized upon, to take sides unequivocally on behalf of the contemporary Russian works." Mooser was a great admirer of Wagner but had no patience for Rachmaninoff. He supported Debussy, but lamented that Elgar was "frighteningly productive and disastrously impersonal."

Anna A. Berman

John Deathridge. 2008. Wagner: Beyond Good and Evil. Berkeley: University of California Press. xiii, 302 pp. ISBN 978-0-520-25453-4.

On the back cover of John Deathridge's Wagner: Beyond Good and Evil, Roger Parker acclaims the book for being that rarity, a "genuinely new" contribution to Wagner scholarship. Parker's claim is a bold one, given the voluminous literature on the subject, and one that possibly does a disservice to Deathridge's work, for Parker's appraisal somewhat misattributes where the importance of this book lies: rather than presenting a radical break from conventional thought on Wagner, as a "genuinely new" book might be expected to do, the book is vital because it collects (albeit in significantly revised form) over fifteen years' worth of research and insights of a renowned Wagnerian scholar. Moreover, taken as a whole, the book attempts to come to terms with why Wagner has been so crucial to history (musical, cultural, and political alike) as well as endeavouring to determine why he continues to be a vital part of our cultural fabric and what he continues to say to us well into the twenty-first century. 
The seventeen essays collected here are thematically organized into six parts running roughly chronologically through Wagner's corpus of work, with discussions of Der Ring des Nibelungen and Tristan und Isolde forming the centrepiece of the book. Part 1, appropriately designated "A Few Beginnings," focuses on Wagner's early pre-Ring work; the title is also appropriate in that its constituent chapters introduce ideas that will be further explored later in the book. With chapter 1, "Wagner Lives," the issue of Wagner and autobiography functions as the beginning for the examination of Wagner as a linchpin figure of modernity. Deathridge questions whether it is possible to recover a cohesive personal history from Wagner's sundry prose writings, especially given his revisionist tendencies. Moreover, Deathridge argues that perhaps searching for consistency is not the desideratum when navigating the frequently messy terrain of Wagnerian autobiography. In a quasi-Foucauldian turn $^{1}$ (though Deathridge does not make the connection), Deathridge contends that the fissures between Wagner's various tellings of his experiences may well be seen as the very things that provide the greatest insight into Wagner himself. As such, he makes a compelling case that Wagner is consequently one of the most underappreciated of modern autobiographers. Chapter 2, "Pale' Senta," touches upon a surprisingly wide array of issues regarding Der fliegende Holländer in its twelve pages, with vampirism, narcissism, self-annihilation, and Heimat all making appearances. Deathridge's willingness to make such a wide and often wild array of associations in such a brief span of pages is what gives the book its distinctive flavour and what makes it such a fascinating read. At the same time, one wishes that Deathridge were more meticulous in dissecting the numerous ideas introduced. Chapter 3, "Wagner the Progressive," is more isolated in its focus and is stronger for it. Deathridge attempts to repair the somewhat deteriorated critical stock of Lohengrin by arguing that it is fundamentally a "progressive" work, showing in inchoate form the significant advances (dramatic and musical) of his subsequent output. Deathridge's points are generally well argued, but a question arises: does Lohengrin's reputation need to be rehabilitated? Moreover, in positing that the work has a long underestimated progressive core, does Deathridge not tacitly imply that the work must be sufficiently "advanced" to be worthy of critical reappraisal? By not acknowledging and confronting this possibility, Deathridge gives the chapter a questionable subtext, regardless of the value of his overall point.

Part 2 is devoted to the Ring cycle, with chapters 4 through 7 focused on each individual opera. The brevity of these chapters betrays their origins as program and CD liner notes and does not attempt to fully develop the ideas presented. These brief essays taken together seem to lay the groundwork for the

1 Foucault's contention is that that the impulse to explain away moments of historical discontinuity in the interest of recovering a linear history should be resisted, for it is those moments of rupture that lay the very groundwork for knowledge. Similarly, Deathridge-noting that the publication of Wagner's "official" biography Mein Leben in 1911 coincided with "the age of Freud and the "new biography" (17)-posits that the contradictory nature of Wagner's writings provides opportunities for psychoanalytic readings potentially efficacious in unearthing the "real" Wagner. 
"meat" of the Ring discussion in part 3. Indeed, the final paragraphs of the Götterdämmerung chapter explicitly announce Deathridge's intentions for part 3, "The Elusiveness of Tragedy." Chapter 8 devotes its attention to the respective endings ${ }^{2}$ of Verdi's Don Carlos and Wagner's Götterdämmerung, interpreted through the lens of Walter Benjamin's study (1977) of the Baroque Trauerspiel, its tendency towards allegory, and its contrast with tragedy. The inclusion of the Verdi example makes sense within the chapter's context but creates a problem when taken as part of the whole: this is the only chapter where a nonWagnerian work is dealt with at length, giving the chapter a sense of it being an "odd man out." Because the remaining chapters do not cover works outside the Wagnerian corpus in detail, the book takes on a feeling of insularity, a feeling that would not have arisen had Deathridge confined his study strictly to Wagner. Chapter 9 considers the other side of the chasm between tragedy and allegory, commenting upon Wagner's complicated thoughts on the Ancient Greeks and the role of tragedy in the "Artwork of the Future." These two chapters are significant for bringing a fresh line of inquiry onto the Ring: for instance, consideration of allegory is often centralized on George Bernard Shaw's conception of the cycle as critique of industrial capitalism. Deathridge opens a fruitful alternative window for deliberation on the allegorical nature of Wagner's work, one that should be further unpacked by future scholars.

Part 4 devotes itself to Tristan und Isolde. In chapter 11, Deathridge foregrounds Wagner's relationship with Mathilde Wesendonck in order to consider the work's gestation as part of a series of tensions between Wagner's public and private life. The chapter features incisive examination of primary sources, while the reference to potential audiences as a Žižekian (by way of Lacan) "big Other" (127) helps set the stage for the concerns of chapter 12, "Postmortem on Isolde." Of particular gravity is Isolde's third act "transfiguration" as an expression of Wagner's ideas about the extra-musical and the musically "absolute." Deathridge focuses on the music analysis-oriented works as well as Michel Poizat's Lacanian readings of the passage. Once again, Deathridge convincingly draws together a wide range of material, both historical and theoretical, but his arguments would have been strengthened at several points by additional references to critical and cultural theory. For example, Deathridge makes reference to Poizat's (1992) and Catherine Clément's (1988) psychoanalytic models of music criticism yet does not invoke other notable psychoanalytic and philosophical readings of instrumental music (and sound in general), such as Kaja Silverman (1988) and Gary Tomlinson (1999), among others. These are puzzling gaps,

2 The discussion of various "endings" functions as a motif that is woven throughout the book: chapter 13 notes that Wagner advertised Parsifal as his "last card" in arguing for the renewal of the Aryan race, while chapter 15 contains talk of the "end" of the symphony, and chapters 16 and 17 discuss the "end" of opera. All of these concerns with artistic endings reach their culmination in the final chapters with discussions of the possibilities of an "end of history," in the sense of that notions of historical progress are eradicated because progress begets only more progress in its wake, perpetually deferring any sense of a final goal. To announce the "end" of the symphony, opera, etc., is to radically break from the bonds of the past and continually create new forms, but with no specific teleological end point in sight. Deathridge will characterize this as the state of "post-history" or "postmodernism." 
when such discourses would seemingly tie directly into Deathridge's discussion of the extra-musicality and "absoluteness" of sonority.

Part 5, "Mature Polemics," begins appropriately enough with an essay on Parsifal, arguably Wagner's most difficult and contested work. The chapter attempts to trace the anxieties over the work's ideologies and ultimately concludes that - as significant a work of art as it is - the tensions it provokes will never completely subside; it will always provoke discomfort. Indeed, Deathridge contends that it is that discomfort that accounts for the work's importance. The chapter concerns itself primarily with Wagner's Gobineau-inspired ${ }^{3}$ obsessions with issues of race, degeneration, and redemption, which were concomitant with the opera's genesis and composition. Deathridge convincingly refutes the arguments of those who have attempted to rescue the opera from the racist mentality of its creator, ${ }^{4}$ but his readings of the score excerpts are far too cursory (limited to a few isolated snippets) to be fully satisfying; the music of Parsifal clearly requires more than a few paragraphs of commentary in order to convincingly integrate it into the larger argument.

Chapters 14 and 15 conclude part 5 by examining two vignettes from Wagner's career-one early, the other late-that illustrate Wagner's complex and contradictory attitudes towards symphonic music. The first instance is centralized on Wagner's early Symphony in C, the full score of which is now lost, and his contentious relationship with Mendelssohn. The second leaps to the end of Wagner's life and the conflict between public and private personas: the former famously declaring the symphony to be unviable after Beethoven, and the latter repeatedly expressing the desire to create symphonic works. The importance of these two chapters is their devotion to a topic all too underrepresented in Wagner scholarship; Deathridge serves us a welcome reminder that Wagner's views on the symphony did not end with the polemics of a man influenced by the tumultuous events of $1848-49$. The symphony remained a vital concern to Wagner, regardless of what his musical and prosaic compositions might have suggested.

If the previous portions of the book attempted to account for Wagner's cultural currency in his own lifetime, part 6, "Operatic Futures," makes strides towards explaining Wagner's endurance as an artistic and cultural force well after his death. Chapter 16, "Configurations of the New," foregrounds Wagner's placement within discourses of newness and modernity, with Deathridge arguing that Wagner's late-period views place him with greater propinquity to radical modernism, even postmodernism, than he is usually given credit for. Deathridge admirably problematizes the traditional tendency to firmly situate Wagner within the discourse of Romanticism; we are persuasively shown

3 Wagner had developed this fascination with the racial theories of Count Joseph Arthur de Gobineau after having read his Essay on the Inequalities of the Human Races in the early 188os; although Wagner had begun composing the music for Parsifal in 1877, before he had read Gobineau's work, Deathridge cannily points out that Wagner's concerns over the "purity" of German blood and "degeneration" of the German line through miscengenation can be traced back to his "Die Wibelungen" essay of 1848 , essentially predating the work of Gobineau.

4 Deathridge singles out the work of Frederic Spotts (1994) and Bryan Magee (2000). 
that Wagner's "modern" aesthetic has clear lineage to the generally accepted practitioners of musical modernism. If the Wagnerian "configuration of the new"s strove to sever the shackles of history, "modernist" composers ironically and perhaps unconsciously employed a Wagnerian aesthetic to overcome the shackles of Wagner. The final chapter, "Wagner and Beyond," aims to follow up from this point, questioning what opera post-Wagner owed to him and what was a conscious deviation from him. Unfortunately, the chapter comes across as more of a coda to the previous essay than something fully formed in its own right. Deathridge ends his discussion in the late 1920 s and early 1930s, but it comes across as an arbitrary stopping point: there is still more "beyond" Wagner to be considered. It might have been more fruitful to reconfigure the previous chapter to include the concerns expressed here, rather than separating them and leaving this one underdeveloped as a result.

Although its shortcomings are not insubstantial, the book is ultimately important for attempting to get to the heart of why Wagner mattered and why he continues to matter; Deathridge is not content to allow Wagner to gather dust as a museum piece, as his efforts to compare and contrast his work with all manner of cultural production can attest. The comparisons sometimes come across as reckless (even bordering on non sequitur), but as previously mentioned that adventurousness makes the book stand out. Moreover, it is of a piece with what I interpret as Deathridge's intent: to make us seriously consider just what "Wagner" means. The book's Nietzsche-inspired subtitle is ultimately completely appropriate: as Deathridge would have it, if Wagner is to endure, he must be read beyond the Manichean separation of "good" and "evil," beyond a compartmentalizing of the "terrible man and his truthful art" (Lee 1999). This is not "beyond good and evil" in the sense that Nietzsche intended, but it might do well to alleviate the partisanships and concomitant misconceptions that Wagner has in the past all too easily provoked.

\section{REFERENCES}

Adorno, Theodor W. 1992. Mahler: A Musical Physiognomy. Translated by Edmund Jephcott. Chicago: University of Chicago Press.

Benjamin, Walter. 1977. The Origin of German Tragic Drama. Translated by John Osborne. London: New Left Books.

Clément, Catherine. 1988. Opera, or, the Undoing of Women. Translated by Betsy Wing. Minneapolis: University of Minnesota Press.

Foucault, Michel. 1972. The Archaeology of Knowledge \& The Discourse on Language. Translated by A.M. Sheridan Smith. New York: Pantheon Books.

Lee, M. Owen. 1999. Wagner: The Terrible Man and His Truthful Art. Toronto: University of Toronto Press.

5 This even has some connection to certain strands of critical theory; when Deathridge notes that Wagner's conception of the new "refilter[s] traditional musical gestures ... so that they are heard critically, if problematically in their new context" (223), compare that to Theodor Adorno's contention (1992) that Mahler deliberately sets "old-fashioned" musical rhetoric against more advanced material in extreme tension so that both "spheres" of music are irrevocably changed. Adorno sets Wagner's progressive core in opposition to Mahler's, but perhaps there is more lineage between them than Adorno was willing to admit. 
Magee, Bryan. 200o. The Tristan Chord: Wagner and Philosophy. New York: Metropolitan Books.

Poizat, Michel. 1992. The Angel's Cry: Beyond the Pleasure Principle in Opera. Translated by Arthur Denner. Ithaca: Cornell University Press.

Shaw, George Bernard. 1981. "The Perfect Wagnerite: A Commentary on The Nibelung's Ring." In 1893-1950. Vol. 3 of Shaw's Music: The Complete Musical Criticism in Three Volumes, ed. Dan H. Laurence, 408-545. London: Bodley Head.

Silverman, Kaja. 1988. The Acoustic Mirror: The Female Voice in Psychoanalysis and Cinema. Bloomington: Indiana University Press.

Spotts, Frederic. 1994. Bayreuth: A History of the Wagner Festival. New Haven: Yale University Press.

Tomlinson, Gary. 1999. Metaphysical Song: An Essay on Opera. Princeton, NJ: Princeton University Press.

DANIEL SHeridan 